\title{
LOCAL FARM BUREAU LEADERSHIP NEEDS ASSESSMENT: A QUALITATIVE STUDY
}

\author{
Eric K. Kaufman, Graduate Research Assistant \\ Rick D. Rudd, Associate Professor \\ University of Florida
}

\begin{abstract}
The purpose of this qualitative study was to determine the leadership expectations, needs, and interests of local Farm Bureau board members. Nine county boards were included in the study, with the chairperson and one other member being interviewed from each board. The focus of the interviews was identification of common leadership-related challenges and perceived development needs of the local Farm Bureau board. Four significant theme areas emerged: organizational appreciation, grassroots involvement, board member training, and board member succession. Within these areas, twelve consistent sub-themes surfaced and are discussed in this paper. Based on these results, the researchers recommended that Florida Farm Bureau: (1) maintain quality field staff as liaisons between the local and state levels; (2) encourage and support district-level leadership programs; (3) develop and facilitate "short courses" on Farm Bureau board governance; (4) design and coordinate new board member orientation programs; (5) expand recognition programs for local board involvement; and (6) continue research efforts that guide local leadership development. Other groups that desire improved local board leadership should consider research efforts similar to this study and the related research with Florida Farm Bureau.
\end{abstract}

\section{Introduction and Framework}

In part, the mission of the American Farm Bureau Federation is "to implement policies that are developed by members" (American Farm Bureau Federation, n.d.). Although the problem of maintaining "grassroots" efforts is a challenge for the entire American Farm Bureau Federation, the changes necessary to address this problem may be most beneficial and effective when led by efforts at a state level. The Florida Farm Bureau Federation (FFBF) has expressed concerns about lack of member involvement and flow of ideas from individual members to the larger organization (Carter, 2004). The leadership of local officers in county Farm Bureau groups has been considered pivotal to the desired flow of organizational ideas and knowledge (Carter). In a study of organizational knowledge, Bryant (2003) found that managing knowledge effectively required conscious effort from leaders at all levels of the organization. Such leaders provide the opportunity for others to create and share new knowledge, resulting in a distinct advantage for the organization as a whole.

Leadership training is grounded in the establishment of network structures that have long-term positive effects on issues (Fredricks, 2003). With this in mind, FFBF has decided to centralize efforts in leadership development programs to improve the leadership skills and practices of the local Farm Bureau members and officers (Carter, 2004).

According to Miller's (1969) systems concept of leadership training, needs assessment is the first process involved in developing a leadership training program. However, as Miller recognized and Bryant (2003) reinforced, assessing the needs of upper-level leaders is not enough. A complete assessment must examine the needs of all levels of leadership. In order for Farm Bureau to maintain its focus on grassroots leadership, a comprehensive needs assessment of local members and 
leaders is crucial. Furthermore, subsequent attempts to improve grassroots efforts must show evidence of success. According to Miller, a key variable indicating the functional success of a training program is the degree of specificity, completeness, and comprehensiveness to which the training process is carried out. The thoroughness involved in assessing the leadership needs of the local Farm Bureau Boards will be critical to the value of the leadership training program offered for Florida Farm Bureau members and leaders.

Although a variety of leadership training models exist throughout the world, none have been identified as potential programs for meeting the leadership needs specific to local Farm Bureau members. Hustedde and Woodward (1996) identified 15 essential public skills which often need to be developed in rural leadership training programs. The skills identified include: active listening, collaboration, conflict resolution, deliberation, evaluation, facilitation, imagination, interviewing, negotiation, power analysis, strategic planning, team building, vigilance, and volunteer management. Some of these skills might correspond to FFBF leadership needs.

According to social cognitive theory, individual performance is neither the result of inner forces nor external stimuli, but rather the result of reciprocal interactions between person, behavior, and environment (Bandura, 1986). As such, leadership must be viewed in terms of an individual's personal desire, their actual behavior, and the impact of their environment. A leadership needs assessment and development program must take into consideration these various aspects of social cognition in order to be effective. This study sought to consider those aspects in a formal needs assessment that would suggest the most appropriate leadership characteristics to be developed among FFBF local board members.

\section{Purpose}

The specific purpose of this study was to determine the leadership expectations, needs, and interests of local Florida Farm
Bureau boards. The following questions guided the study:

1. What are the leadership-related challenges common to local Farm Bureau boards?

2. What are the perceived development needs of local Farm Bureau board members?

\section{Methods and Procedures}

Qualitative methods were used to collect, analyze, and interpret the data in this study. Data collection consisted of interviews and observation. As Sogunro (2001) found in his research surrounding a leadership training program, qualitative research can be effective in understanding a social or human problem that may involve many variables.

The research proposal for this study was presented to the FFBF Executive Director of Organization and Programs, and then the entire group of "field staff," for input and validation. Field staff are the paid employees of the state federation who serve as liaisons between the county Farm Bureau unit and the state organization (Florida Farm Bureau, n.d.). Proposed correspondence and interview questions were reviewed and approved by the FFBF Executive Director for Organization and Programs and the Director of Field Services. The interview questions and observation criteria were pilot tested with a FFBF county board that was not included in this study.

The population for this study included nine purposefully selected county boards within the FFBF. A board meeting was observed in each county and two board members from each county were interviewed $(N=9$ observations, $\quad \mathrm{N}=18$ interviews). Interview participants included the board chairperson and one other board member. Meeting participants included in the observation were board members, Farm Bureau staff, and invited guests. The use of multiple data-collection methods and sources, commonly referred to as triangulation, contributes to the trustworthiness of the data (Glesne, 1999).

State-level leaders for FFBF were consulted to appropriately select 
representative county boards for participation in the study. Nonprobability sampling was used to seek geographic diversity; the researchers made an effort to have representation from each of the eight Farm Bureau designated geographic regions of the state. Although, several attempts to arrange for data collection in district one (the Florida panhandle) were unsuccessful, data was collected from at least one county board in all other FFBF districts.

Initial contacts regarding individual county board participation in the study were made through the Farm Bureau district field directors. The researchers then sent a letter of introduction (on Florida Farm Bureau letterhead) to each board president. The letter provided a brief overview of the study and indicated that contact would be made by phone during the week prior to the next scheduled meeting. During the phone communication, arrangements were made to meet the president prior to the board meeting and conduct personal interviews. The board chairperson was asked to identify a second interviewee for participation in the study.

Participant interviews ranged from 10 to 45 minutes in length. A digital audio recorder and researcher note taking were used for data collection. As Lincoln and Guba (1985) found, audio files allow for repeated review to ensure full understanding, while note taking provides the opportunity to identify non-verbal cues and highlight items of importance. The audio files were professionally transcribed, and the transcriptions served as the primary data source for this study.

Although the board chairperson and selected board member from each county Farm Bureau board were interviewed separately, each interview was framed with the same questions. In developing the questions, the researchers considered the related questions in Carter's (2004) research with Farm Bureau. The questions were refined based on feedback from Florida Farm Bureau staff and the pilot test. The following questions were asked during the interviews:
1. What is your name and position or affiliation with Farm Bureau?

2. How many years have you served on the board?

3. How often does the board meet and, typically, for how long?

4. Does the board have an annual retreat or planning meeting of any kind?

5. How are committee assignments made?

6. What do you like best about board meetings? What do you like least?

7. What do you believe makes an effective county board?

8. What personal skills do you expect county board members to have?

9. Typically, why do board members "step down" from their positions on the board?

10. What educational programs would you like to see offered for county board members?

11. What talents or characteristics is the board seeking in new members?

12. How are members' expectations of each other and the organization communicated?

13. What is the relationship between the board and Farm Bureau staff members?

14. What knowledge do county board members need to have about Farm Bureau? Do most county members have this knowledge?

15. What is the role of the county boards in the state Farm Bureau organization?

In addition to field notes from the interviews, secondary data for this study was collected through observations of the local board meetings in the selected counties. During the meetings, the researcher observed members and actions of the board as a whole using observation techniques and pre-selected criteria.

Once the data was collected, it was interpreted using content analysis to identify noticeable patterns or themes. The basic purpose of content analysis is to organize 
and simplify data into meaningful and manageable themes or categories (Patton, 1987). The data was triangulated by comparing the interview responses of the different individuals in each county and comparing the emerged themes with conclusions drawn by Carter (2004) in her random survey of FFBF board members. An additional source of triangulation was secondary data collected as field notes.

Credibility (internal validity) for this study was addressed by confirming the emerging hypotheses with the FFBF field staff who regularly work with all of the county boards across the state. The list of interview themes determined by the researchers, along with related excerpts from the transcriptions, was E-mailed to the entire field staff team for their assessment. Responses from the FFBF staff were supportive of the findings. One of the district field directors shared, "I would say that is a pretty accurate statement of the counties I have worked with over the years. I think you hit the nail on the head" (B. Shaw, personal communication, November 16, 2004).
Transferability (external validity) of this study may be accomplished by others who are able to consider the descriptive detail in determining if the findings are applicable to other situations. The researchers made no attempt to generalize the results to other populations.

Dependability was addressed in the study by keeping detailed records of the data collection and analysis procedures. Confirmability was addressed in the study by including "thick descriptions" and excerpts from the raw data that support interpretations and conclusions drawn by the researchers.

\section{Findings and Conclusions}

Based on the interviews with county Farm Bureau board members, four significant theme areas emerged in every county studied. Those themes include organizational appreciation, grassroots involvement, board member training, and board member succession. Common subthemes observed in each area are reported in Table 1.

Table 1

Common Themes from Interviews with Florida Farm Bureau Board Members in Nine Counties

\begin{tabular}{ll}
\hline Theme Area & Sub-Theme \\
\hline Organizational appreciation & Farm Bureau pride \\
& Helpful field staff \\
Grassroots involvement & County boards ensure local focus \\
& Significant time required for effective board \\
& Community involvement is an important role \\
& Political advocacy is an important role \\
& Board member orientation or training is desired \\
Board member training & Communication skills are essential \\
& Farm Bureau organizational knowledge is essential \\
& Long board tenures exist - for better or worse \\
Board member succession & Board recruitment is difficult \\
& Disaffection for long, unfocused meetings \\
\hline
\end{tabular}


Numerous excerpts from the transcribed interviews stand out in support of each theme area and specific sub-theme. The quotes, as included in this article, have been coded in an effort to maintain anonymity of the subjects. A number is used to identify each unique county and a letter " $A$ " or " $B$ " has been assigned to the specific individual within each county. An "A" indicates that a board chairperson made the statement, while a "B" indicates that a board member other than the chair made the statement. When necessary, proper names were replaced by an appropriate description placed in brackets. Occasionally, a word was added to the direct quote in order to assist the reader in understanding the context. In these cases, the word has been placed in brackets to identify it as an addition to the quotation.

\section{Organizational appreciation}

The organizational appreciation theme area was represented by two sub-themes expressed in all nine counties. Those subthemes are: (1) Farm Bureau pride and (2) helpful field staff.

Statements of organizational pride were common throughout the interviews. For example, participant 7A said, "I am just proud of what our county Farm Bureau has been able to do." Most board members concluded their interview with an unsolicited statement about their pride in being associated with Farm Bureau. Participant 1B said, "Farm Bureau is a good organization; I am proud to be part of it." Another (5B) said, "I believe strongly in Farm Bureau; I think it is a good organization.” Participant 4B described the appreciation further:

I really appreciate what Farm Bureau [has done] - and I am talking national on down to the state and even on the county level. You know, it has been good for me to grow. I can't think of anybody that I've met involving Farm Bureau that aren't just the finest folks in the world... the kind of people you have over for supper.

Positive statements regarding field staff were also made by participants in every county. One participant (3B) said, "I can go to [our field director] about anything that I want to at Farm Bureau and not feel out of place or awkward." Another board member (3A) went on to say:

He has just been a great leader to me on what we need to have done. So even though I probably know that he is underpaid and works long hours and things - [our field director] wouldn't want me to say that - but he loves what he does. And we certainly appreciate him here in [our] county, but we couldn't do it without [our field director].

\section{Grassroots Involvement}

Specific sub-themes for grassroots involvement that emerged in all nine counties include: (1) county boards ensure local focus, (2) significant time required for effective board, (3) community involvement is an important role, and (4) political advocacy is an important role.

Participants often defined the local board's role in the larger organization as "grassroots." They explained, "We are what makes Farm Bureau" (5B). "It is the county boards that help the state organization determine its role on issues and to help guide it as to what it needs to address" (7A). Some board members interviewed were not direct in using the term "grassroots," yet they described the county board's role as ensuring a local focus. Participant 8A said, "[We] give direction and guidance to the state boards on what issues are affecting us in our county that can be combated, you know, at a state or national level." In essence, the local board's role is "to make sure the county is being run on county levels" (1B).

Study participants believed that effectively fulfilling the role of the county board requires a significant time commitment. "Involvement is the key" (5B). The least desirable part of board participation is often "the time involved" (8B). "It gives you an opportunity to get involved, but you get spread awful thin" (5A). Another participant (4B) explained, "Time is money; and we are all so 'doggone' busy and pulled 15 directions these days, but if you agree to serve you agreed to 
put the time in." As such, in looking for prospective board members, it was said:

The biggest thing we are seeking is people who are willing to commit with their time to get involved: the time to attend board meetings, the time to attend committee meetings, the time to go out and speak with elected officials and participate in the various other activities that we have going on. (7A)

The importance of community involvement was a related sub-theme. "It is one thing to come to a meeting once a month and converse for an hour or so, and it's another thing to actually get out there and deal with local problems" (7B). In describing the role of county boards, one participant explained, "Number one we are supposed to be promoting agriculture within our community” (4B). Another participant said, "As a group here in our county, we have to get a more active board" (8A). The characteristics sought in new board members include "involvement in the community and industry” (5A).

Similarly, board members recognize the importance of political advocacy as a part of their responsibilities. Boards "need to be able to successfully address local, as well as state and national issues, and get involved in the grassroots, political involvement of Farm Bureau” (7A). One interviewee (5A) explained further, "We play a very critical role in lobbying, and I think that is probably one of the most important functions." This importance was reflected in suggestions for board-related educational programs. One board member (8A) expressed particular interest in having a program on "how to deal with the PACs and how to lobby our local representatives and state representatives." Another (1B) expressed interest in "legislative type meetings, how to deal with government people and also with media." The desire is that new board members "are willing to attend meetings, and go to Washington D.C. and lobby, [and] go to Tallahassee and lobby” (7B).

Board Member Training

Within the theme area of board member training, all participating county boards shared three common sub-themes: (1) board member orientation or training is desired, (2) communication skills are essential, and (3) Farm Bureau organizational knowledge is essential.

Suggestions for board member orientation or training varied from an area retreat to a local short course to a reference book. The common element among all counties interviewed was that something more is desired. One board member (1A) said, "We all need to have a leadership course." Another board member (5A) shared:

I think if we had an executive retreat or an overnight stay or a planning deal, a day or something, just team work building you know, something fun. I think [it] would help build your team a little more and build relationships. Any time we work together that helps bond us - I could see if we had a little retreat and one good person from Gainesville come down and give us a pep talk and send us in the right direction.

Still another participant (7A) said:

I would love to see the state organization do a county board member training and get representation from all of the county boards together for a day or a weekend and have a conference to train them in the various board member responsibilities.

Specific topics sought for board training included: "board functions," "bylaws," "rules," and "insurance" (2B); "how to make a motion" (4A); "leadership," as well as "budget and finance" (4B); "teamwork building" (5A); "organizational type[s] of skills" (5B); "policies and procedures for the board" (6A); "how the system works" (8B); and others, particularly in communication and organizational knowledge.

Participants in each county believed communication skills are essential for board success. Participant 3B summed it up by saying, "Communication is the key." When asked what personal skills board members should have, the responses were clear: "They need to be able to communicate; that 
would be probably the most important thing" (4A); "Communication skills definitely" (9B); "Communicate well: with communicating their feelings and their beliefs with the board, potential Farm Bureau members, and with our community" (5A); "Be able to communicate with our elected officials and our members" (8A); "Dealing with the press" (3B); and so on. Board members would also like to have more communication and information sharing within the organization. Participant 7A said:

One area that I feel that the state organization is lacking, it is not sharing enough information. You know we need to have better meetings amongst representation of county Farm Bureaus to share our successes and failures and learn from each other.

Agreement existed among all counties on the importance of Farm Bureau organizational knowledge. What knowledge do county board members need to have about Farm Bureau? Participants responded by saying: "They need to know about everything, as much as they can" (2A), "As much as possible" (4B), and "Probably a lot more than I have got" (6B). Another (8A) expanded, saying, "I don't have the grasp or an understanding of the way the state program transfers down to our local counties.” Other board members recognized this problem, saying, "I would say most of our board members do not know a great deal about Farm Bureau” (5A) and

A lot of people come to Farm Bureau and they don't understand Farm Bureau at all. I know when I came I had no clue what Farm Bureau was. I was asked to be on the board, and I was willing, but the first year I was clueless, and I think there ought to be some kind of program that when you are new to a board you have got to go to it. You know, they need to tell you what it is about and what you are trying to accomplish. I think that is very important. (4A)

As a solution, one board member (5A) recommended "a new member/new director program - even if it is a book." Participants explained: "There needs to be, like, more training on how the state program directly affects the county" (8A); "We need to know where we stand on particular issues as a Farm Bureau group” (6B).

\section{Board Member Succession}

Within the theme area of board member succession, interview statements suggest the following thee sub-themes: (1) long board tenures exist - for better or worse; (2) board recruitment is difficult; and (3) disaffection for long, unfocused meetings.

As for the length of board tenures, it was said, "We very seldom have one to step down; most of our board members are long time board members" (9A). Also in response to the question of why board members "step down", another participant said, “Typically they don't. I think that is a problem that we need to address here. I think it is not only a problem in [our] county but from talking with other county boards it is a problem statewide" (8A). He went on to say: "The boards of the local Farm Bureau have been a 'click.' It has been 'old-timey' family members that have been here for generations and they have controlled and run the boards and agriculture has changed." Participant (8B) contributed:

We have got some long time members and I don't know whether that is good or bad. I think a certain amount of that is good because you keep continuity and your history going, but when you get too much of that you don't get the young blood coming in behind you.

Similarly, participant 5A said, "We have a pretty good retention rate on our directors. I don't know if that is good or bad. It makes it hard to get rid of the 'dead wood' if there is sometimes.” Another president (4A) said:

Our board members are - and I am assuming like a lot of boards, not necessarily just Farm Bureau - they have been here forever. You know, they have been there, done that. You know, at first they were "gun ho," like the young ones coming, but then after the years go by 
they just kind of sit back and there is really no participation out of them.

As for recruiting new board members, most board members considered it to be a difficult task. Participant 9A said:

With the Ag people getting smaller and smaller, it is pretty hard to get a person to serve on a board like this because people are extremely busy in their own operations and some people won't give their time, you know, to do a board job.

Another member (8A) shared:

We need to get out of that mindset, the old school mindset that is the old families and the old board members and we need to be looking for smaller people in agriculture that can broaden our voice; and that is a problem here.

Toward this goal, one participant (5B) said, "I won't walk away from the board; but if they find somebody that would be very energetic and wants to serve, I would gladly step down." Participant 8A has assessed the problem by saying, "Agriculture has changed but our boards have not and the make up of our boards have not."

For members who do continue to serve on their local board, the least desirable component of their commitment is often "long meetings" (3B). "Sometimes they are boring; they get drawn out, and certain members tend to be long winded" (9B). One board member (5B) shared, "Sometimes they can get a little long winded, and at times the lack of formality can also be a hindrance to conducting business or getting anything done efficiently and getting out of here." Participant 3B said, "Certain board members and certain staff, or whatever, have their own little pet peeves, and they like to take up more than their allotted time. And it gets on your nerves when it happens time after time after time." So, how did board members consistently respond when asked about the least favorite part of their involvement? "I guess the thing I dislike most is when the board begins to ramble and sort of lose its focus there" (6A).

\section{Discussion, Implications, and Recommendations}

All of the findings from this study support the views of social cognitive theory in suggesting that current leadership practices and desired leadership skills rely heavily upon reciprocal interactions among person, behavior, and environment (Bandura, 1986). Some themes that emerged from the interviews may seem obvious to those familiar with Florida Farm Bureau, but the findings are important since the interviews have provided evidence of some perceptions that may have been assumed in the past.

Connections can be made in comparing the theme areas and sub-themes to the public skills that Hustedde and Woodward (1996) identified for rural leadership development. Certainly the sub-theme of difficult board recruitment relates to the public skill of volunteer management. The facilitation skill might match well with the sub-themes that address disaffection for long, unfocused meetings and the importance of communication. Hustedde and Woodward might also associate vigilance skills with Farm Bureau board member's long tenures and time commitments to the board. Other public skills identified by Hustedde and Woodward could also be loosely associated with the leadership development needs of FFBF board members. These connections provide encouraging opportunities to adapt resources recommended by Hustedde and Woodward for use with Florida Farm Bureau boards.

When considering previous FFBF findings, a rather clear picture of board members can be seen. Many of the statements made by county board members match up with the expectations for board effectiveness described by the FFBF state leadership (Carter, 2004). Those theme areas included leadership, political process, effective boards, and knowledge of Farm Bureau. The results described in this paper also match well with the findings from the local board member questionnaire administered by Carter. Consistent with the grassroots theme area, Carter reported that a majority of board members were involved in at least one civic, community, or business 
organization. In addition, the desire to have board members respected in their communities was the leadership statement rated with the highest mean level of importance. Carter also found noticeable gaps between perceived importance and proficiency of various leadership skills and in "Knowledge of the American Farm Bureau Federation."

The findings of this study cannot be generalized to other populations; however, the researchers would suggest that other organizations and programs have the potential to benefit from conclusions about appropriate leadership needs of local Florida Farm Bureau boards studied here. Other state Farm Bureau federations, other grassroots organizations, or even other private agricultural groups within the United States may consider using this process to direct research among their board members.

Based on the emerged theme areas and findings from this study, the researchers recommend that the Florida Farm Bureau Federation proceed with the following interventions:

1. Maintain quality field staff as liaisons between the local and state levels;

2. Encourage and support district level leadership programs;

3. Develop and facilitate "short courses" on Farm Bureau board governance;

4. Design and coordinate new board member orientation programs;

5. Expand recognition programs for local board involvement; and

6. Continue research efforts that guide local leadership development.

Field directors are sometimes the only contact local board members have with the larger organization and are often able to develop a sense of organizational appreciation among these members. Quality field directors are also an essential component in providing state-level assistance and services for the local boards. As such, efforts should be made to maintain high-quality staff in these positions. When new field staff are being recruited, it may be worthwhile to include local board members in the hiring process.

Some districts already have district leadership programs in place; however, board members in districts without such programs have expressed interest in developing and participating in a program that facilitates discussion among multiple county Farm Bureaus. Improved collaboration has the potential to broaden grassroots involvement, thus increasing the effectiveness of local Farm Bureau leadership.

Short courses on Farm Bureau governance could be provided at the district or county level. The curriculum should be designed to allow for presentation at regular county board meetings, district leadership meetings, or annual board retreats. Recommended short courses include: communication skills, Farm Bureau basics, meeting management, political advocacy, financial management, and board member recruitment/succession.

New board member orientation programs would have the advantage of bringing new board members "up to speed" with the knowledge that long-time board members have taken for granted. Because so few new board members are elected each year, it may be most appropriate for this new orientation to take place at a statewide event. If local boards expect new board members to attend a formal orientation at the FFBF state convention, new board members would gain exposure to the organization even beyond the potential scope of the orientation.

Because local boards consist of volunteers and may be reluctant to commit time toward new programs offered at the state level, they may require encouragement. Florida Farm Bureau should consider further development of its capacity to generate, educate, mobilize, and sustain volunteer board members. The GEMS Model for volunteer management may be appropriate to apply in this situation (Culp, Deppe, Castillo, \& Wells, 1998).

Continued research with Florida Farm Bureau is essential for implementing these steps in leadership development. As Miller's (1969) training model indicates, leadership development is an integrated 
process involving needs assessment, objective setting, design, implementation, and evaluation - each affecting the other. As such, objectives set for any new Farm Bureau programs should correspond with appropriate evaluation criteria. In this way, an objective assessment can be made as to whether or not the interventions create any change among participants. To this end, the leadership assessment survey for county board members that was developed by Carter (2004) could be used in connection with the Borich (1980) needs assessment model for conducting follow-up studies. Positive changes in the perceived importance and/or proficiency of various leadership abilities would suggest some degree of success from the interventions; at the same time, new leadership needs may surface that provide direction for continued intervention.

Other groups that desire improved local board leadership should consider research efforts similar to this study and the related research with Florida Farm Bureau. As Carver (1997) has argued, governing boards are generally understudied and underdeveloped. Continued research in this area provides the opportunity to change that problem and create a positive future for the organizations served by these governing boards.

\section{References}

American Farm Bureau Federation. (n.d.). We are Farm Bureau. Retrieved April 14, 2005, from www.fb.org/about/thisis/ wearefarmbureau.pdf

Bandura, A. (1986). Social foundations of thought and action: A social cognitive theory. Englewood Cliffs, NJ: Prentice-Hall.

Borich, G. D. (1980). A needs assessment model for conducting follow-up studies. Journal of Teacher Education, 31(3), 39-42.
Bryant, S. E. (2003). The role of transformational and transactional leadership in creating, sharing and exploiting organizational knowledge. The Journal of Leadership and Organizational Studies, 4, 32-44.

Carter, H. (2004). Leadership attitude, will, and desire of Florida Farm Bureau. University of Florida, Gainesville, FL.

Carver, J. (1997). Boards that make a difference: a new design for leadership in nonprofit and public organizations (2nd ed.). San Francisco: Jossey-Bass.

Culp, K., Deppe, C. A., Castillo, J. X., \& Wells, B. J. (1998). The GEMS Model of volunteer administration. The Journal of Volunteer Administration, 16(4), 36-40.

Florida Farm Bureau. (n.d.). Florida Farm Bureau field staff. Retrieved November 23, 2004, from http://www. floridafarmbureau.org/directory/field.html

Fredricks, S. M. (2003). Creating and maintaining networks among leaders: an exploratory case study of two leadership training programs. The Journal of Leadership and Organizational Studies, 1, 45-54.

Glesne, C. (1999). Becoming qualitative researchers: An introduction (2nd ed.). New York: Addison Wesley Longman.

Hustedde, R. J., \& Woodward, A. (1996). Designing a rural leadership program and curriculum, IP-54. Retrieved April 14, 2005, from www.ca.uky.edu/agc /pubs/ip/ip54/ip54.pdf

Lincoln, Y. S., \& Guba, E. G. (1985). Naturalistic inquiry. Newbury Park, CA: Sage Publications. 
Miller, R. D. (1969). A systems concept of training. Training \& Development Journal, 23(4), 4-14.

Patton, M. Q. (1987). How to use qualitative methods in evaluation (2nd ed. Vol. 4). Newbury Park, CA: Sage Publications.
Sogunro, O. A. (2001). Selecting a quantitative or qualitative research methodology: An experience. Educational Research Quarterly, 26(1), 3-10.

ERIC K. KAUFMAN is a Graduate Research Assistant in the Department of Agricultural Education and Communication at the University of Florida, 310 Rolfs Hall, P. O. Box 110540, Gainesville FL 32611-0540. E-mail: kaufmane@ufl.edu.

RICK D. RUDD is an Associate Professor in the Department of Agricultural Education and Communication at the University of Florida, 218 Rolfs Hall, P. O. Box 110540, Gainesville FL 32611-0540. E-mail: rrudd@ufl.edu. 